\title{
Performance Evaluation of Pakistan's Mutual Fund through CAPM and Fama French 3-Factor Model
}

\author{
Syeda Zain Fatima \\ MPhil: Accounting and Finance \\ Department of: Accounting and Finance \\ University of Central Punjab Lahore \\ Muhammad Haroon \\ MPhil: Accounting and Finance \\ Department of: Accounting and Finance \\ University of Central Punjab Lahore
}

\begin{abstract}
Mutual fund is selection for the common investors for investing in to the capital market. In the research paper Capital Asset Pricing Model (CAPM) and FAMA French 3 factor model applied for the measurement and evaluate the performance of the mutual fund. Daily data of mutual fund which are selected in open ended mutual fund of Pakistan and daily data collected from 2010 to 2016. Then applied these models and Capital Assets Pricing Model showed the significant result and $\mathbf{R}^{2}$ value more co-related with the market returns and premium. FAMA French 3 factor model showed the not good results with the two factors SMB and HML. Time series regression model are applied between two competing models.
\end{abstract}

Keywords: Mutual funds, Capital Assets Pricing Model, FAMA French 3 factor model.

\section{INTRODUCTION}

With the increase in trend of investment of investors which consider the mutual fund is the key instrument of profitability. Mutual fund is pool saving a number of investors. The underpinning objective of investment in mutual funds is profitability numerous studies documented the same evidence over the period of time. The fund investors have objective for the Common investment by the Asset Management Company (AMC). Mutual fund creates profitability through dividend, capital gain and appreciation of share price. Mutual Fund avail liquidity and portfolio management enterprise, diversification of risk and stability of stock market and mobiles saving which attaching funds from the small investor. In history of mutual fund introduce the name of investment fund. King William I launched first mutual fund close and open end investment fund in Netherland 1822. On the point Dutch Mechant named Adrian Van Kasich whose created investment 1977 given the idea of King William. Kitwish probably theorized that diversification would increase the capital investment with small capital. The next ways of the mutual fund investment launched in Switzerland in 1849 by vehicle of Scotland in 1880 .

Mutual fund introduced in Pakistan in 1962. Establishment of Investment Company of National Corporation of Pakistan (ICP) offered publically of national investment trust (NIT) in 1966. Mutual fund registered in Pakistan and in form of trust legally established under the trust, Act 1882. Security and exchange commission of Pakistan (SECP) regulate the mutual fund industry of each asset management company in strict compliance with the NBFC rules, 2003 and determine all AMC's to acquire an independent rating. 
Mutual fund categorized in three types: close end mutual fund, open-end mutual fund, and exchange traded fund.

- Open-end mutual fund shares purchase and sale on demand on their net asset value, or NAV, which base on the value of the fund's securities.

- Close-end funds are traded between the investors on exchange which have a fixed numbers of shares. Like stock, according to supply and demand their share prices are determined and are traded at discount or premium to their net asset value'

- Exchange-traded funds are also traded on their market price value like stock on exchange which are more closely at their net present value than close-end mutual fund and usually stay on the premium and discount within $1 \%$ of NAV, with exception of some smaller ETFs that are frequently in trade.

Many tools and measures analyzed the measurement of the performance of the mutual fund. Capital Asset Pricing Model (CAPM) that explain the relationship between expected return of assets and systematic risk, other stocks. Finance for the risky securities of price used by CAPM, explained expected returns for assets given the risk of those assets and calculating cost of capital.

Harry Markowitz considered the father of Modern Portfolio Theory (MPT) in 1950's and published in Makowitz, 1952. The portfolio made about60 years old. Most of mutual funds employees earn on the basis of MPT manage the funds. Firstly Markowitz show relationship between risk and return and tell us how to minimize the risk. William sharp, John Lintner and Jan Mossin developed the asset pricing model in mid-1960's. Therefore the model mentioned to as sharp-Lintner-Mossin Capital Asset Pricing Model (CAPM).

Formula for calculating the expected return of an asset its risk is as follows:

$\mathrm{Rf}=$ risk free rate

$$
\mathrm{Ra}=\mathrm{Rf}+\beta(\mathrm{Rm}-\mathrm{Rf})
$$

$\beta=$ beta of the security

$\mathrm{Rm}=$ expected market risk

In 1990 American economist William p sharp, harry Markowitz and Merton h. miller won the noble prize "for their introducing the new idea and methods in the theory of financial economics". In the 1960's Sharp, taking off from Markowitz's portfolio theory, established the Capital Asset Pricing Model (CAPM) Sharp, 1964. This model is fit in every investor's portfolio on the basis of single mix of risky assets. Investor's wants more return and carry weighted portfolio with the risky asset. Portfolio risk measure cannot be modified without beta. Asset pricing under short sale examined to restrain and analysis about effect of cross sectional idiosyncratic risk Miller, 1977. To forecast the diversified portfolio risk that idiosyncratic risk should be priced when investor hold undiversified and diversified portfolio Merton, 1987. Idiosyncratic risk should be linked with cross section risk. Blume 1970, Friends and Blume 1970 and Black, Jensen and Scholes 1972 examine the portfolios estimated beta instead of individual securities. In portfolio expected return and market betas work combine or same way of CAPM. The critical errors in variables problem are reduced by cross sectional portfolio regression of average return on betas. It reduces statistical power and also reduces the range of betas. To alleviate the problem, researchers classify the securities on beta when float portfolio and $1^{\text {st }}$ portfolio have lowest beta on the securities, as far as the last portfolios process the highest beta assets. In empirical test is classifying the procedure. Correlation of the residuals in cross section regression is caused on propose a method for addressing for inference the problem. 
The time series intercepts monthly slopes and in addition to the standard errors of means. The slopes monthly to monthly variate in regression coefficients and determine the problem actually estimating correlations. The residual correlation effect the regression coefficient. These conversations also become standard in literature. The relationship between market beta and expected return implicit of a time series regression test by Sharp-Lintner in 1968.

$\mathrm{R}_{\mathrm{i}}{ }^{\mathrm{t}}=$ asset's return

EXPECTED VALUE OF AN ASSET'S EXCESS RETURN $=\mathbf{R}_{\mathbf{i}}{ }^{\mathbf{t}}-\mathbf{R}^{\mathbf{f}}$

$\mathrm{R}^{\mathrm{f}}=$ risk free interest rate

It determine expected risk premium of CAPM which its beta time of expected value.

Risk premium $=\mathrm{R}^{\mathrm{m}}-\mathrm{R}^{\mathbf{f}}$

$\mathrm{R}^{\mathrm{m}}=$ Market risk

$\mathrm{R}^{\mathrm{f}}=$ Risk free interest rate

Jenson Alpha suggested intercept term in the time-series regression.

\section{(Time series regression) $R_{\mathrm{i}} \mathrm{t}-\mathrm{Rf}=\boldsymbol{\alpha}_{\mathrm{i}}+\boldsymbol{\beta}_{\mathrm{i}} \mathrm{m} *(\mathrm{Rmt}-\mathrm{Rft})+\varepsilon_{\mathrm{i}} \mathrm{t}$}

In Sharp-Lintner version of CAPM, have positive relation between beta and average return. In this model cross section model intercept the risk free rate and coefficient of beta is expected market return more than risk free rate.

Fama and Macbeth(1973) introduced further explain about cross section regression test, like Fama and French(1992).It confirmed in time series tests due to relationship between beta and average return. Fama French 2-factor and Fama French 3-factor expanded after Fama French single model of (Fama, 1993). Charhart extended to these factors with the help of CAPM and introduced Fama French 4-factor model in (1997). Beta, Size factor and value factor covered in the 3-factor model. Fama French 4-factor model used to measure mutual fund performance in Developed Countries.it is also known as MOM factor (monthly momentum). An active management and mutual fund evaluation model worked as a 4-factor model. Monthly momentum explained about the stock price tendency which continuously up and down.

In different financial market has been determined mutual funds by extensive research and in Pakistan limited work on mutual fund. The purpose of this study is to point out the significant variables influencing the fund performance provide the manager of open ended and close ended Pakistan's mutual funds and benefit for small investor (Rauf, 2009).

All used traditional methods to determine the performance of the mutual fund of Pakistan and also arise question about the credibility of modern methods of Mutual Fund performance in Pakistan. To evaluate, measure and test mutual fund performance are organized for filling the gap of this study through competing the models i.e. CAPM and Fama French 3-factor models to forecast and evaluate the performance of mutual fund and explain that which one is better performed for portfolio return. Research focused to achieve following objectives:

- To evaluate and measure the performance of the mutual fund through competing models like CAPM model and Fama French 3-factor model.

- To investigate and test viable of these models and explain which one model is better perform in mutual fund of Pakistan.

\section{LITERATURE REVIEW}

Efficient Market portfolio, investors fascinated and discussed about the portfolio minimize the risk and maximize the assets return. Most of the mutual fund employees earn on the basis of 
Modern Portfolio Theory managed the funds and also specified of efficient portfolio frontier (Makowitz, 1952).In 1960 sharp and Lintner 1965 modified the capital asset pricing model. Investors have desired to carry more return and weighted portfolio with risky asset. Portfolio risk measured and modified without beta and introduced the risk free asset in the Model (Sharp, 1964). In 1973 Fama and Macbeth explained the cross section of regression test model. In 1977 Miller examined the assets pricing model under the short sale restrain and analysis about effect of cross sectional idiosyncratic risk. (Stephen F. Witt, 1979) In 1987 Merton forecast the diversified portfolio risk that idiosyncratic risk priced when investor hold diversified portfolio and create positive relationship between cross section return and risk. Idiosyncratic risk linked with cross section risk. (French, Common Risk Factors in the Returns on Stock and bond, 1993) Fama French further explained to the factors which effected on risk beta and return. Fama French 2 factors and 3 factors evaluate the performance of mutual fund and took the results of value, size and market factors. 4 factors model established for evaluate the performance of stock and fund. Researcher used momentum which calculated weighted average of the low performance the firm from the equal performance high weighted average of firm (Carhart, 1997). In describe towards a strategic theory of risk premium moving beyond CAPM .In Pakistan used the old methods for evaluation of the mutual fund performance (S, 1990). In 2003 Eugene F. Fama and Kenneth R.French introduced the CAPM theory and evidence and create relationship between risk and expected returns. In The CAPM theory evaluated the risk and market return and its evidence (French, 2004). The performance evaluate of mutual fund of Pakistan. In this study calculate the sharp ratio analysis for measuring the risk and return. 26 close end mutual fund has been selected some are private and some are public sector. The open end Mutual funds and close end mutual funds total net assets value merge and then graphically show the model. 14 funds out of 33 funds reset and operationally used for research purpose (Hijazi, 2005). Sharp ratio, Treynor model, Jensen differential measure is used in this research. Capital Asset Pricing Model is also used in that study (Rauf, 2009). The performance analyzed the mutual fund. Its provide the open ended Pakistan's mutual fund and benefits to the small investor and sharp ratio measure the performance of the mutual fund with the help of time series and cross sectional data and focus on fund size expenses, age etc (Nawaz, 2010). In this research create the size and value of market return and also calculated the stock returns and check the momentum in risk and returns. The Capital Asset Pricing Model (CAPM) explained with drawdown measure the active portfolio management (French, Siza, Value, and Momentum in International Stock Returns, 2010), (Michael Zabarankin, 2014), (Marios, 2014)

Analyze of mutual fund performance using multiple measure for calculating the causality and normality in the data. Implement on the Fama French Factor Model for calculating the risk which correlated between market risks premiums (Asim Shah, 2014) (Babar Rafi, 2014). Fama French model used to check the momentum variation. Studied about applicability of Fama French, Three-Factor Model on the bases of KSE 100 index and explained cross-sectional return on equity market of Pakistan (Nahzat Abbas, 2015). In this research daily data collected of KSE100 index and merge and calculate returns then checked daily fluctuation in the market. SMB and HML calculate for Fama French 3 factor model and applied time series regression model for checking relationship between dependent and independent variable (Andleeb, 2014). Fama French and Capital Asset Pricing Models implement in stock market of Saudi Arabia through compared the real rate with the returns using CAPM and FF.Fama French 3 factor investigated the size, book-to-market and market return to Saudi Arabia which approach use for measuring the dependent and independent variables and effects on risk factors affected on the return (Abdulaziz Aldaarmi, 2015).

Mutual Fund evaluated performance and validated the CAPM and Fama French 3 model. One 
hundred open ended Pakistan mutual funds collected month wise data from 2009 to 2015 by both models (Baloch, 2015). Capital Asset Pricing Model showed significant and checked the relationship between 2 variables. SMB and HML evaluated the performance of actual risk premium with the help of size of market capitalization and market to book value size and arrange the portfolio returns (Bhatti, 2015). The Capital Asset Pricing Mode evaluated risk then calculated the Alfa with help of CAPM. This research focus on the returns through CAPM model compare with high and low returns after the comparison high returns does not show the variation in the market and need to other methods for calculating the and measures the variations in to the market. This research needs to best measurement tools for evaluation of Mutual Funds.

\section{HYPOTHESES}

H0: Capital Asset Pricing Model (CAPM) and Fama French 3 factors do not equally forecast for evaluating the Mutual Fund performance of Pakistan.

H1: Capital Asset Pricing Model (CAPM) and Fama French 3 factors equally forecast for evaluating the Mutual Fund performance of Pakistan.

\section{RESEARCH METHODOLOGY}

This is regression and correlation study for Mutual Fund. Mutual Fund portfolios adjusted with overall market premium. The total 157 open ended mutual funds are traded in the MUFAP and are also population of this study. Sample size 24 funds are randomly selected. These selected funds data collected in different ways which are as follows:

- Daily data of mutual fund have been calculated by MUFAP data for the period of 2010 to 2016.

- Daily T-bills rates have been calculated for the 2010 to 2016 and merged with the daily data of mutual fund.

- KSE100 index data also calculated stock price from 2010 to 2016 for SMB and HML factors.

- The daily data of funds merged with financial data of stock.

- Market capitalization created and calculated returns. Generated the size and rank of the firms with the selection of the groups big and small which are further new groups Low, Medium and High.

- Further generated six portfolios in each day and portfolio BH, BM, BL SH, SM, SL. B for big size and S for small size. H, M and L are for High, Medium and Low. $\backslash$

- Generated SMB and HML factors $\mathrm{SMB}=(\mathrm{SH}+\mathrm{SM}+\mathrm{SL}) / 3-(\mathrm{BH}+\mathrm{BM}+\mathrm{BL}) / 3$ and $\mathrm{HML}=(\mathrm{BL}+\mathrm{SL}) / 2-(\mathrm{BH}+\mathrm{SH}) / 2$

- Applied time series regression model.

\section{RESEARCH MODEL}

Capital Asset Pricing Model (CAPM) and Fama French-3 factor model explained bellow:

- Capital Asset Pricing Model (CAPM):

CAPM model is used for evaluating the mutual fund performance of Pakistan (Baloch A. R., 2015).

Where

$$
(\mathrm{Ri}-\mathrm{Rf})=\boldsymbol{\alpha}+\beta(\mathrm{Rm}-\mathrm{Rf})+\varepsilon
$$

Rf represents risk free rate of the stock.

(Ri-Rf) represent given stocks risk premium.

Represents $\beta$ (Rm - Rf) expected risk premium and intercept the $\boldsymbol{\alpha}$ Alfa for CAPM. 
FAMA FRENCH-3 MODEL:

In the studies tested for the Mutual Fund performance evaluation by (Baloch A. R., 2015).

$$
(\mathrm{Ri}-\mathrm{Rf})=\boldsymbol{\alpha}+\beta 1(\mathrm{Rm}-\mathrm{Rf})+\beta 2(\mathrm{SMB})+\beta 3(\mathrm{HML})+\varepsilon
$$

(Ri - Rf) represents stock risk premium.

$\beta(\mathrm{Rm}$ - Rf) represent the expected risk premium

SMB denotes the daily premium of the factor size of the returns of the portfolio that contain small caps funds and HML denotes the daily market factors and contains large caps. SML and HML calculated for returns portfolio of market and stock and then intercepts with Alfa $\boldsymbol{\alpha}$. SMB and HML calculated for FAMA French-3 factor Model, Rm and Rf is also used for Capital Asset Pricing Model (CAPM).

\section{DATA ANALYSIS}

Capital Assets Pricing Model (CAPM) and Fama French model measures the mutual fund performance.

Table 1:

In this table the results are showing the CAPM. These results show that due to market factor significantly related with all portfolio returns. All portfolios of returns P1 to P24 have significant coefficient. The portfolio of higher return do not properly explain and predict bigger in values compare with the lower perform portfolios. The portfolios with the high return have significant intercept but compared with the high and low portfolios of return. The results show that CAPM perform poorly in explaining with the high and low returns. Fund with higher and lower returns are not predicted good by CAPM which mean that fund manager do not cope well capture the market variation.

Table 2:

FAMA French-3 Factor Model indicates the SMB and HML factors. It showing significant results of 24 portfolios of return which explained by Fama French 3- Factor model. The results are showing that significant results of market factor and intercepts the both SMB and HML factors mostly insignificant. Its mean that do not have sufficient explanatory power of size of factors and value of the factors. So the results explained that Fama French model do not properly prediction of the performance of mutual funds of Pakistan.

Table 3:

In table 3 , selected the 24 funds of companies in which mean value is much closer to the zero. Beta shows that measurement of risk but some companies have negative beta but they have positive coefficient relationship between market return and companies return. CAPM perform well as compared to the Fama French model.

\section{FINDINGS AND CONCLUSIONS}

Mutual fund plays important role for common investors in the world, mutual fund gives the more opportunities and benefits for the capital investment through skillful and professional management. In this research apply suitable models for measuring the performance of mutual fund in Pakistan. Daily data of open end ended mutual fund selected and randomly analyzed. Period of 2010 to 2016 analyzed the sample fund. To generate the results FAMA French-3 Factor Model and CAPM model applied. Firstly CAPM calculated by time series regression model and show the significance relationship between variables. It shows good perform in this Model. FAMA French - 3 Factor Model do not shows good results on both SMB and HML. Market factor presents the significance coefficients for the test. Capital Assets Pricing Model more acceptable for creating relation between market risk and return. FAMA French -3 factor 
model results do not properly capture variation in to the market of Pakistan.

About this research supports properly for good investing strategy.Inthe research market variation concerned with the market factor effect on the Mutual Funds of Pakistan. Capital assets pricing model measures the Mutual fund of Pakistan and perform well in Pakistan. FAMA French - 3 Factor Model do not show good results for the funds and it also does not capture the market size and value of the all over the market premium. FAMA French 3 factor model evaluate the Mutual fund performance in the developed countries like U.S.A etc. these findings almost match with the previous research. Fund manager focus on the value and size factors which effect on mutual fund performance. Measurement tools and strategies for evaluating the performance of Mutual Fund conducted in the Pakistan in future. FAMA French 4 factor model and FAMA French 5 factor model will be conducted in Pakistan for the measurement of the close end mutual funds and open ends mutual funds.

\section{References:}

Abdulaziz Aldaarmi, M. A. (2015, May/June). Implement Fama and French And Capital Asset Pricing Model In Saudi Aribia Stock Market. The Journal of Applied Business Research, 31(3), 1-16.

Andleeb, R. S. (2014). Islamic Capital Asset Pricing Model. Islamic Banking and Finance, 2(1), 187-195.

Asim Shah, A. G. (2014). Estimation of FAMA and French Model with Augmented Risk Factor. International Journal of Business and Management, 9(9), 1833-3850.

Babar Rafi, S. S. (2014, August 30). Validity of FAMA and French Model Evidence from KSE-100 index. International Journal of Management Sciences, 3(1), 52-57.

Baloch, A. R. (2015). Evaluating Pakistan' Mutual Fund Performance: Validating through CAPM and Fama French 3- Factor Model. Journal of Managerial Sciences, 1-10.

Baloch, A. R. (2015). Evaluating Pakistan's Mutual Fund Performance: Validating through CAPM and Fama French 3- FACTOR Model. Journal of Managerial Sciences, 173-182.

Bhatti, G. A. (2015). Performance Evaluation of Equity Mutual Funds of Pakistan. Pakistan Journal of Social Sciences, 35(2), 681-689.

Carhart, M. (1997). On persistence in Mutual Fund Performance. The Journal of Finance, 5(1), 57-82.

Fama, E. F. (1993). Common Risk Factor in the Returns on the stocks and bonds. Finance Economics, 33(1), 3-56.

French, E. F. (1993). Common Risk Factors in the Returns on Stock and bond. Journal of Finance Economics, 33(1), 3-56.

French, E. F. (2004). The Capital Asset Pricing Model and Evidence. Journal of Economic Perspectives, 18(3), 2546.

French, E. F. (2010, February). Siza, Value, and Momentum in International Stock Returns. Journal of Finance Economics, 12(1), 1-45.

Hijazi, S. M. (2005). Performance Evaluation of Mutual Funds of Pakistan. The Pakistan Development Review, 44(4), 556-567.

Makowitz, H. (1952, March). Portfolio Selection. The Journal of Finance, 07(01), 77 to 91.

Marios, L. (2014, February). Evaluation of Mutual Fund Performance using multiple measure. The Journal of Finance, 32(1), 1-234.

Merton. (1987). A Simple Model of Capital Market Equilibrium in Incomplet information. Journal of Finance, 42, 483 to 510 .

Michael Zabarankin, K. P. (2014). Capital Asset Pricing Model (CAPM) with drawdown measure. European Journal Of Operational Reserch, 234(2), 508-517.

Miller. (1977). Risk Uncertainty and and Diversification of opinion. Journal of finance, 32, 1151 to 1168.

Nahzat Abbas, J. K. (2015). A study to Check The Applicability of FAMA and French, Three- Factor Model on KSE100- Index. International Journal of Finance Research, 6(1), 1923-4023. 
Nawaz, M. S. (2010). The Determinants of Mutualn Fund Growth in Pakistan. International Research Journal of Finance and Economics, 146(54), 1450-2887.

Rauf, T. A. (2009). Performance Evaluation of Pakistan Mutual Funds. Pakistan Economic and Social review, 47(2), 199-214.

S, M. H. (1990). Note Towards a Strategic Theory of Risk Premium. Academic and Management Review, 24(3), 556-567.

Sharp, W. (1964). Capital Asset Prices: A Theory of Market Equilibrium under Condition of Risk. Journal of Finance, 19, 587 to 616 .

Stephen F. Witt, R. D. (1979). The Markowitz Contribution to Portfolio Theory. Managerial Finance, 5(1), 3-17. 
Table 1: CAPM

\begin{tabular}{|l|r|r|r|r|r|r|}
\hline Variables & portfolio1 & portfolio2 & portfolio3 & portfolio4 & portfolio5 & portfolio6 \\
\hline RM-RF & & & & & & \\
\hline & -0.07621 & 0.15939 & 0.02658 & 0.00219 & -0.04813 & 0.05213 \\
\hline Constant & 0.01316 & -0.00279 & 0.05224 & -0.44115 & 0.81014 & 0.10609 \\
\hline
\end{tabular}

\begin{tabular}{|c|c|c|c|c|c|c|}
\hline Variables & portfolio7 & portfolio8 & portfolio9 & portfolio10 & portfolio11 & portfolio12 \\
\hline & & & & & & \\
\hline RM-RF & 0.00331 & 0.00366 & 0.01389 & -0.01165 & -0.03433 & 0.01527 \\
\hline & & & & & & \\
\hline Constant & -0.59537 & -0.65476 & -0.27702 & 0.26317 & 0.07929 & -0.03687 \\
\hline
\end{tabular}

\begin{tabular}{|c|r|c|c|c|c|c|}
\hline Variables & portfolio13 & portfolio14 & portfolio15 & portfolio16 & portfolio17 & portfolio18 \\
\hline & & & & & & \\
\hline RM-RF & 0.00180 & 0.00125 & 0.00158 & 0.00184 & 0.01045 & 0.08299 \\
\hline & & & & & & \\
\hline Constant & -0.32461 & -0.23721 & -0.29674 & -0.34192 & -0.02100 & 0.01767 \\
\hline
\end{tabular}

\begin{tabular}{|c|r|c|c|c|c|c|}
\hline Variables & portfolio19 & Portfolio20 & Portfolio21 & Portfolio22 & Portfolio23 & Portfolio24 \\
\hline & & & & & & \\
\hline RM-RF & 0.00070 & 0.00290 & -0.01089 & 0.00234 & -0.03545 & 0.12130 \\
\hline & & & & & & \\
\hline Constant & 0.00410 & -0.54600 & 0.0267 & -0.43620 & 0.06335 & -0.00237 \\
\hline
\end{tabular}


Table 2: FAMA French 3 factor model

\begin{tabular}{|l|l|l|l|l|l|l|}
\hline Variables & portfolio1 & portfolio2 & portfolio3 & portfolio4 & portfolio5 & portfolio6 \\
\hline & & & & & & \\
\hline int & $3.312 \mathrm{E}-05$ & -0.0002699 & -0.000677 & $-6.41 \mathrm{E}-05$ & -0.0001383 & -0.000192 \\
\hline & & & & & & \\
\hline RM-RF & -0.1775421 & 0.1200165 & -0.000342 & -0.0015787 & 0.06729009 & 0.3154901 \\
\hline & & & & & & \\
\hline SMB & 0.1203294 & -0.0979289 & -0.001282 & 0.0009419 & -0.0395283 & -0.201195 \\
\hline & & & & & & \\
\hline HML & 0.1503992 & -0.4288858 & 1.181944 & 0.24307659 & -0.658549 & -0.27072 \\
\hline & & & & & & \\
\hline Constant & -0.6772758 & 0.0672122 & -1.36875 & -0.6891775 & 0.8921152 & 1.028551 \\
\hline
\end{tabular}

\begin{tabular}{|c|c|c|c|c|c|r|}
\hline Variables & portfolio7 & portfolio8 & portfolio9 & portfolio10 & portfolio11 & portfolio12 \\
\hline & & & & & & \\
\hline Int & $-7.718 \mathrm{E}-05$ & $-7.42 \mathrm{E}-05$ & -0.000533 & $-5.775 \mathrm{E}-05$ & $-2.93 \mathrm{E}-05$ & $4.933 \mathrm{E}-05$ \\
\hline & & & & & & \\
\hline RM-RF & -0.0011868 & 0.0011904 & -0.001469 & 0.04274777 & 0.02370884 & -0.0069016 \\
\hline & & & & & & \\
\hline SMB & 0.0009664 & -0.001048 & 0.0010418 & -0.0250399 & -0.0081353 & 0.0023461 \\
\hline & & & & & & \\
\hline HML & 0.2636465 & 0.0165472 & 0.9985556 & -0.3690119 & -0.2136057 & 0.55317 \\
\hline & & & & & & \\
\hline Constant & -1.146071 & 0.4255717 & -0.331023 & 0.11223566 & -1.2908236 & 0.2197722 \\
\hline
\end{tabular}

\begin{tabular}{|c|c|c|c|c|c|r|}
\hline Variables & portfolio13 & portfolio14 & portfolio15 & portfolio16 & portfolio17 & portfolio18 \\
\hline & & & & & & \\
\hline Int & $-6.18 \mathrm{E}-05$ & $-4.439 \mathrm{E}-05$ & $-4.577 \mathrm{E}-05$ & $-7.422 \mathrm{E}-05$ & -0.000283 & -0.000218 \\
\hline & & & & & & \\
\hline RM-RF & $-3.97 \mathrm{E}-05$ & -0.0007854 & -0.0013335 & 0.0018847 & -0.002564 & 0.0985935 \\
\hline & & & & & & \\
\hline SMB & $3.218 \mathrm{E}-06$ & 0.0005193 & 0.00079286 & -0.0011092 & 0.001176 & -0.07377 \\
\hline & & & & & & \\
\hline HML & 0.1042868 & 0.14406548 & 0.19472662 & -0.0438578 & 0.7079022 & -0.769715 \\
\hline & & & & & & \\
\hline Constant & -0.295277 & -0.4466802 & -0.5557038 & 0.2084331 & -1.407415 & 0.4157611 \\
\hline
\end{tabular}

\begin{tabular}{|c|r|r|r|r|r|r|}
\hline Variables & portfolio19 & portfolio20 & portfolio21 & portfolio22 & portfolio23 & portfolio24 \\
\hline Int & $-4.973 \mathrm{E}-05$ & $-5.63 \mathrm{E}-05$ & $2.248 \mathrm{E}-05$ & $-7.161 \mathrm{E}-05$ & $-2.838 \mathrm{E}-05$ & -0.0003051 \\
\hline & & & & & & \\
\hline RM-RF & -0.33364 & -0.001318 & 0.0458489 & 0.0002389 & -0.1150334 & 0.0523588 \\
\hline & & & & & & \\
\hline SMB & 0.2184219 & 0.0006404 & -0.0266729 & -0.0002039 & 0.0777638 & -0.0505325 \\
\hline & & & & & & \\
\hline HML & 0.2927677 & 0.2114485 & -0.3939274 & 0.1025473 & 0.9932337 & -0.3883472 \\
\hline & & & & & & \\
\hline Constant & -1.104061 & -0.353626 & 0.1108972 & -0.1848115 & -0.4268066 & 0.4063627 \\
\hline
\end{tabular}


Table 3:

\begin{tabular}{|c|c|c|c|c|}
\hline Companies funds & Beta & $\begin{array}{r}\text { Correlation } \\
\text { coefficient }\end{array}$ & Covariances & Variances \\
\hline ABL INCOME FUND & $0.031843^{-}$ & -0.042594013 & $-2.71482 \mathrm{E}-06$ & $4.76779 \mathrm{E}-05$ \\
\hline ABLSF & 0.245021 & 0.032925456 & $1.56798 \mathrm{E}-08$ & 0.000354597 \\
\hline AKDFOF & 0.001142 & 0.006940652 & 5.44143E-08 & $1.29067 \mathrm{E}-06$ \\
\hline A GHP IF & 0.000014 & -0.002442173 & $-5.06528 \mathrm{E}-09$ & $1.21458 \mathrm{E}-08$ \\
\hline Alfalah value fund & 0.338643 & 0.014166862 & $4.36821 \mathrm{E}-07$ & 0.000737482 \\
\hline UNIT TRUST OF PAKISTAN & $0.564476^{-}$ & -0.001888056 & $-6.852 \mathrm{E}-09$ & 0.001085642 \\
\hline NIT income fund & 0.000755 & -0.007334114 & $-5.56622 \mathrm{E}-07$ & 7.81951E-06 \\
\hline NIT Govt bond fund & 0.000020 & 0.000742052 & 2.11973E-08 & $7.52508 \mathrm{E}-07$ \\
\hline NI(U)T fund & 0.000985 & -0.003162513 & $-7.70018 \mathrm{E}-09$ & 7.59039E-07 \\
\hline $\begin{array}{l}\text { NAFA INCOME OPPORTUNITY } \\
\text { FUND }\end{array}$ & 0.490761 & -0.074603945 & $-3.69087 \mathrm{E}-07$ & $3.25632 \mathrm{E}-05$ \\
\hline NAFA INCOME FUND & 0.184144 & -0.02966752 & $-1.39691 \mathrm{E}-07$ & $2.92426 \mathrm{E}-05$ \\
\hline $\begin{array}{l}\text { NAFA GOVT SECURITY LIQUID } \\
\text { FUND }\end{array}$ & 0.003662 & -0.010393096 & $-1.19188 \mathrm{E}-07$ & 4.04349E-06 \\
\hline MCB dfc INCOME FUND & 0.000196 & -0.010515383 & $-5.73901 E-09$ & $1.0198 \mathrm{E}-08$ \\
\hline $\begin{array}{l}\text { MCB CASH MANAGEMENT } \\
\text { OPTIMISER }\end{array}$ & 0.000478 & 0.013156302 & $1.92983 \mathrm{E}-09$ & $5.32746 \mathrm{E}-09$ \\
\hline LAKSON MONEY MARKET FUND & 0.310000 & 0.337464366 & 3.15953E-09 & 8.60559E-09 \\
\hline LAKSON INCOME FUND & 1.113514 & 0.375461419 & 5.92875E-09 & 4.68577E-08 \\
\hline LAKSON EQUITY FUND & 1.312818 & 0.199576468 & $1.1291 \mathrm{E}-08$ & $3.72367 \mathrm{E}-07$ \\
\hline JS GROWTH FUND & 0.302093 & -0.005182677 & $-1.41471 \mathrm{E}-08$ & 0.000159204 \\
\hline JS FUNDS OF FUND & 0.552887 & -0.004120441 & $-2.05757 \mathrm{E}-07$ & 0.006704351 \\
\hline JS CASH FUND & 0.000052 & 0.00385199 & 8.32192E-09 & $2.93514 \mathrm{E}-08$ \\
\hline HBL INCOME FUND & $0.000111^{-}$ & -0.002137744 & $-7.42751 \mathrm{E}-07$ & $1.80271 \mathrm{E}-05$ \\
\hline Faysal income and growth fund & 0.233652 & 0.235771844 & 6.85402E-09 & 2.88259E-08 \\
\hline Atlas Income fund & 0.005817 & -0.005716022 & $-1.0481 E-07$ & $1.86722 \mathrm{E}-05$ \\
\hline Askari equiety fund & 0.181332 & 0.003880585 & $5.22402 \mathrm{E}-09$ & $6.29416 \mathrm{E}-05$ \\
\hline
\end{tabular}

